\title{
Аналіз загальних показників, рівнів та структури захворюваності військовослужбовців строкової служби Національної гвардії України
}

\author{
ТОВ «Органосін ЛТД», м. Рівне, Україна
}

\begin{abstract}
Мета. Аналіз показників, рівнів та структури захворюваності серед військовослужбовців строкової служби Національної гвардї (НГ) Украӥни.

Матеріали і.методи. Для досягнення мети проводився підбір та вивчення даних статистичних звітів медичної служби за формою 264а, проаналізованих та узагальнених фахівиями лікувально-профілактичного відділу Військово-медичного управління Головного управління Національної гвардії України щуодо загальної захворюваності військовослужбовців.

При цьому вивчалися рівень, структура $і$ динаміка захворюваності серед військовослужбовців строкової служби відповідно до Оперативних територіальних об'єднань за основними класами хвороб за кожен рік в період з 2014 по 2018 рік та середні за п'ять років з використанням статистичного методу дослідження.

При розподілі класів хвороб військовослужбовців НГ Украӥни використана Міжнародна класифікація хвороб - МКХ-10. Результати. Проведений аналіз рівня, структури та динаміки захворюваності у військовослужбовців строкової служби Національної гвардї Украӥни упродовж 2014-2018 років, результати якого свідчать про зростання показників захворюваності серед досліджуваного контингенту. Вивчення загальної структури захворюваності військовослужбовиів Національної гвардії Украӥни надає загальну уяву про найбільш розповсюджені хвороби серед особового складу військ. Це дуже важливо для прогнозування та планування кадрового та матеріального медичного забезпечення військ.

Висновки. Вивчення загальної структури захворюваності військовослужбовців строкової служби Національної гвардії Украӥни надає загальну уяву про найбільш розповсюджені хвороби, які зустрічаються серед особового складу військ. Це дуже важливо при прогнозуванні та плануванні кадрового та матеріального медичного забезпечення військ.

Ключові слова: рівні, показники захворюваності, захворюваність, військовослужбовці Національної гвардї.
\end{abstract}

\section{Вступ}

3 доров’я народу - один 3 найважливіших інтегрованих показників соціальноекономічного й екологічного благополуччя суспільства, його демографічного, культурного та оборонного потенціалу. Стан здоров'я військовослужбовців - вагомий чинник боєздатності військ, який має важливе економічне та соціальне значення [1].

Здоров'я військовослужбовців можна вважати як баланс між його якістю і якістю середовища перебування, тобто станом всього комплексу умов військової праці і побуту [2].

В сучасних умовах особливого значення набуває пізнання закономірностей формування здоров'я військовослужбовців, оцінка зрушень, визначення тенденцій, вивчення соціально-гігієнічних проблем здоров'я $[3,4]$.

Традиційно важливими для оцінки стану здоров'я військовослужбовців вважаються показники захворюваності.

Високий рівень захворюваності може відображати не тільки погіршення стану здоров'я, але і належне функціонування системи охорони здоров'я та високу доступність медичної допомоги, яка обумовлюється розвитком мережі медичних закладів, медичних технологій, функціонуванням системи моніторингу стану здоров'я, кваліфікацією медичного персоналу та іншими факторами. Відповідно низький рівень захворюваності та інтенсивності звернень за медичною допомогою на фоні високої смертності свідчить про малодоступність (низьку якість) медичного обслуговування та проблеми зі здоров'ям в контингентах населення, що досліджуються.

Вивчення захворюваності досліджуваного контингенту дозволяє більш раціонально планувати та організовувати медичну допомогу військовослужбовцям, спостерігати за динамічними змінами в їх здоров 'ї, а також в певній мірі дає уяву про поширеність деяких захворювань. [5, 6].

Аналіз показників та структури захворюваності серед військовослужбовців строкової служби Національної гвардії (НГ) України.

\section{Матеріали та методи}

Для досягнення мети проводився підбір та вивчення даних статистичних звітів медичної служби за формою 264a, проаналізованих та узагальнених фахівцями лікувально-профілактичного відділу Військовомедичного управління Головного управління Національної гвардії України щодо загальної захворюваності військовослужбовців.

При цьому вивчалися рівень, структура і динаміка захворюваності серед військовослужбовців строкової служби відповідно до Оперативних територіальних об'єднань [7] за основними класами хвороб за кожен рік в період з 2014 по 2018 рік та середні за п'ять років 3 використанням статистичного методу дослідження. 
При розподілі класів хвороб військовослужбовців НГ України використана Міжнародна класифікація хвороб - МКХ-10.

\section{Результати дослідження та їх обговорення}

Нами був проведений аналіз показників загальної захворюваності військовослужбовців Національної гвардії України в середньому за 2014-2018 рр. 3 урахуванням категорій військовослужбовців (строкова служба) та Оперативних територіальних об'єднань (ОТО). Загальна захворюваність у військовослужбовців строкової служби відповідно до Оперативних територіальних об'єднань становила $1298,4 \%$ у Західному ОТО, 2135,2\%о у Південному ОТО, 1967,7\%о у Північному ОТО, 2015,6\% у Східному ОТО, 1896,6\%о у Центральному ОТО (рис. 1).

Загальні рівні захворюваності у військовослужбовців строкової служби Центрального ОТО за класами хвороб мали тенденцію до збільшення показників з 862,9\%о в 2014 році до 2254,2\%о в 2018 році.

В структурі загальної захворюваності військовослужбовців строкової служби Центрального ОТО перше місце займали хвороби органів дихання (Х клас) - 52,2\% 3 показником 985,1\%о. Показники даного класу мали тенденцію до зростання з 468,7\% у 2014 році до $1097 \%$ у 2018 році (рис. 2).

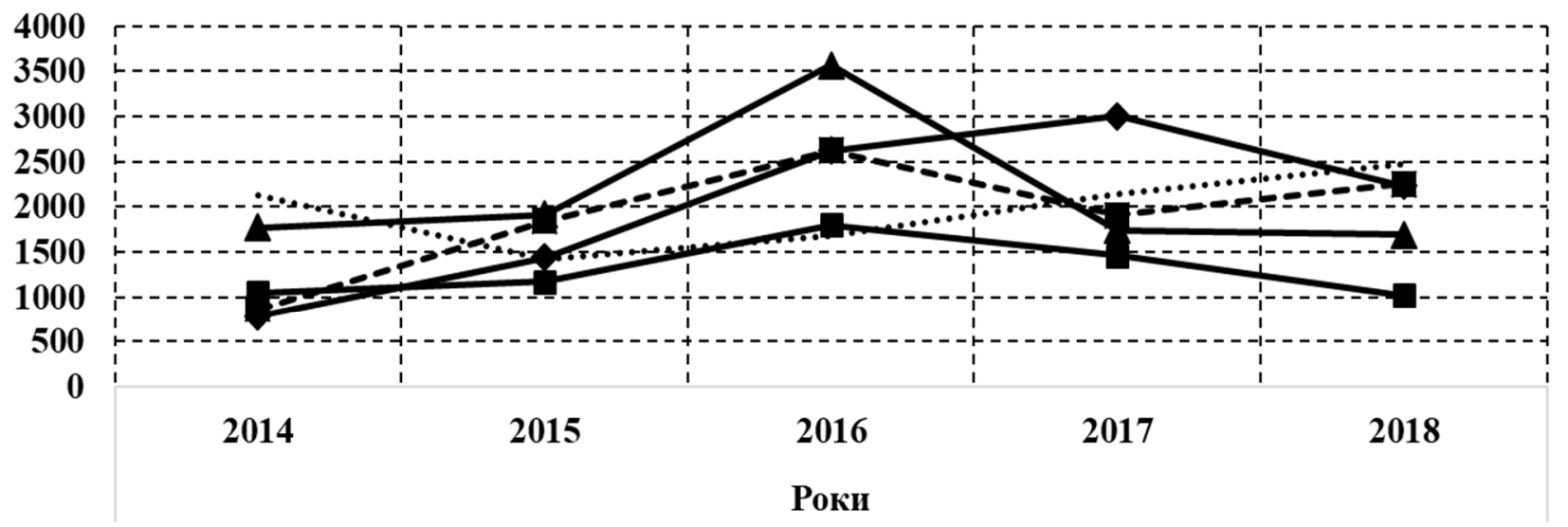

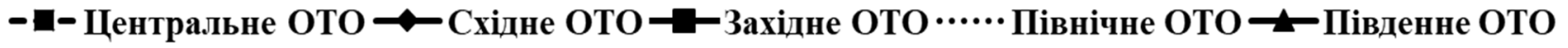

Рис. 1. Динаміка рівнів загальної захворюваності серед військовослужбовиів строкової служби НГ Украӥни в середньому за 2014-2018 роки

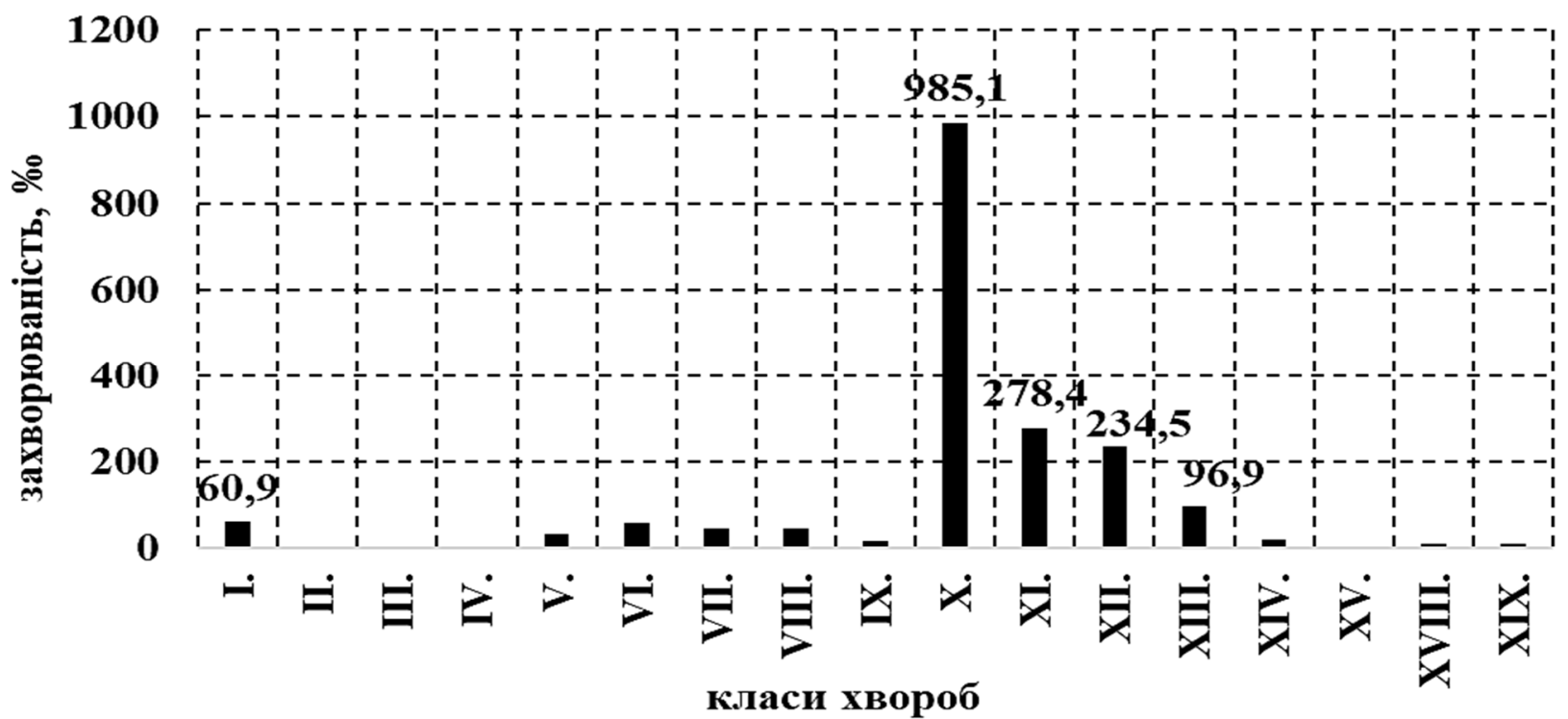

Рис. 2. Показники загальної захворюваності військовослужбовців строкової служби Центрального ОТО по класам хвороб в середньому за 2014-2018 роки

Друге рангове місце в структурі захворюваності тенденцію до зростання з 118,8\%о у 2014 році до $250,8 \%$ рядового складу займали хвороби органів травлення - у 2018 році. 14,6\% 3 показником 278,4\%. Показники XI класу мали 
Трете рангове місце займали хвороби шкіри та підшкірної клітковини (XII клас), вони становили $12 \%$ $(234,5 \%$ ). Показники зростали з $87,5 \%$ у 2014 році до $232,4 \%$ у 2018 році.

Четверте місце - хвороби кістково-м'язової системи та сполучної тканини (XIII клас), вони становили 4,9\% (96,8\%). Відмічалося зростання показників 3 46\% у 2014 році до $104 \%$ у 2018 році.

П'яте рангове місце в структурі захворюваності рядового складу займали деякі інфекційні та паразитарні хвороби (I клас), які складали $3 \% \quad 3$ показником захворюваності $60,9 \%$. У даного класу також спостерігалось зростання показників 3 47,4\% у 2014 році до $76,9 \%$ у 2018 році.

Загальні рівні захворюваності у військовослужбовців строкової служби Східного ОТО за класами хвороб мали тенденцію до зростання показників 3 782,4\%о в 2014 році до $2228,7 \%$ в 2018 році.

В структурі загальної захворюваності військовослужбовців строкової служби Східного ОТО перше місце займали хвороби органів дихання (X клас) 47,7 \% 3 показником 954,03\%. Показники даного класу мали тенденцію до значного зростання 3 321,3\%о у 2014 році до 1214,2\% у 2018 році (рис. 3).

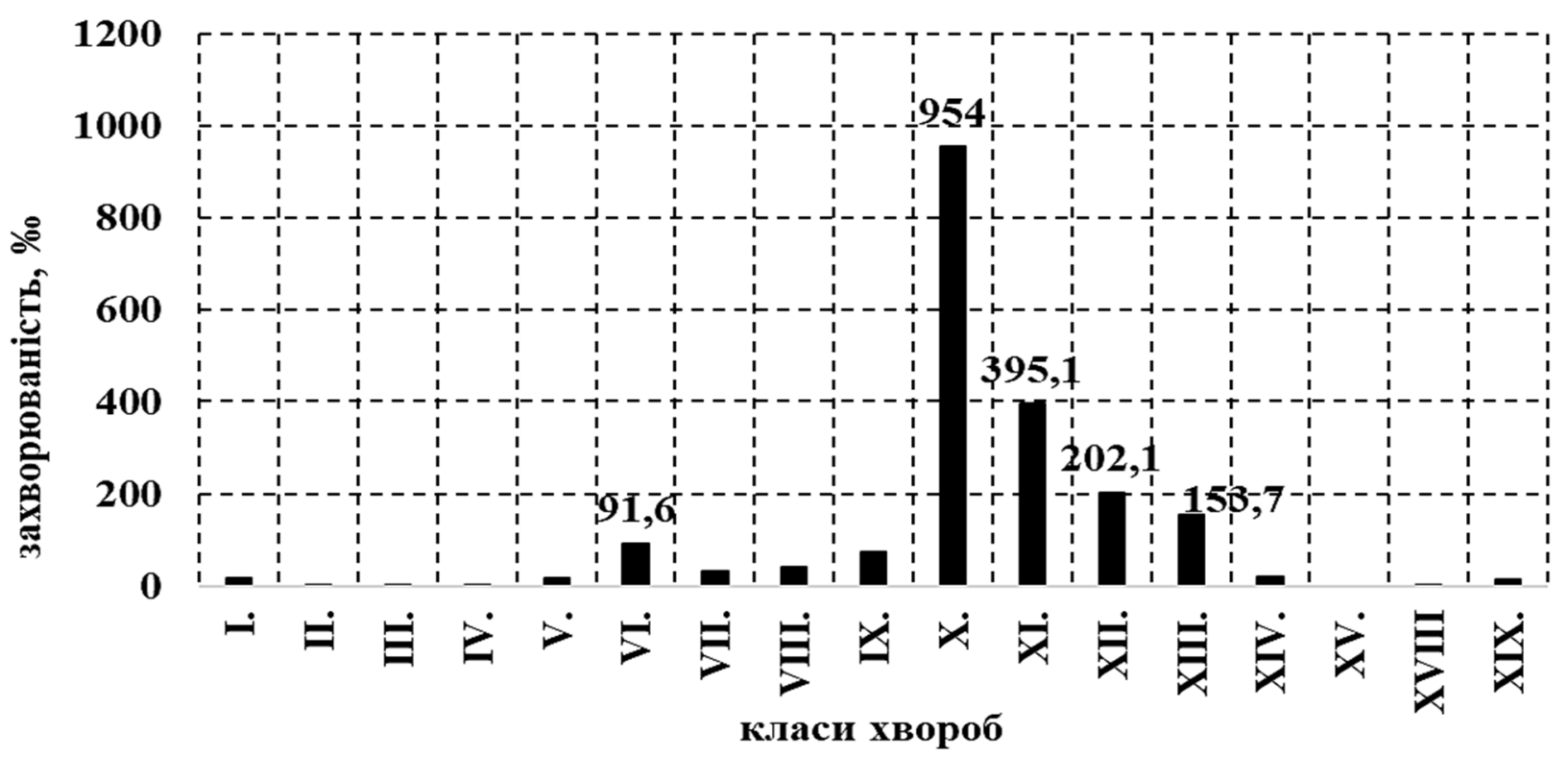

Рис. 3. Показники загальної захворюваності військовослужбовичів строкової служби Східного ОТО по класам хвороб в середньому за 2014-2018 роки

Друге рангове місце в структурі захворюваності рядового складу займали хвороби органів травлення 19,4\% 3 показником 395,1\%. Показники ХІ класу мали тенденцію до зростання показників з 146,1\%о у 2014 році до $332,6 \%$ у 2018 році.

Третє рангове місце займали хвороби шкіри та підшкірної клітковини (XII клас), вони становили 9,7\% $(202,1 \%)$. Показники зростали $373,5 \%$ у 2014 році до $181,4 \%$ у 2018 році.

Четверте місце - хвороби кістково-м'язової системи та сполучної тканини (XIII клас), вони становили 7,3\% $(153,7 \%$ ). Відмічалося зростання показників з 49,8\%о у 2014 році до $104 \%$ у 2018 році.

П'яте рангове місце в структурі захворюваності рядового складу займали хвороби нервової системи (VI клас), які складали 4,8\% 3 показником захворюваності 91,6\%. У даного класу також спостерігалось зростання показників з 14,8\% у 2014 році до $156,6 \%$ у 2018 році.

Загальні рівні захворюваності у

військовослужбовців строкової служби Західного ОТО за класами хвороб мали тенденцію до незначного зниження показників з 1047,4\%о в 2014 році до 1017,1\%о в 2018 році.
В структурі загальної захворюваності військовослужбовців строкової служби Західного ОТО перше місце займали хвороби органів дихання (X клас) 50,9\% з показником 665,9\%о. Показники даного класу мали тенденцію до незначного зростання з 527,9\%о у 2014 році до 602,2\% у 2018 році (рис. 4).

Друге рангове місце в структурі захворюваності рядового складу займали хвороби органів травлення $15,9 \% 3$ показником 214,8\%о. Показники XI класу мали тенденцію до зниження з 218,1\%о у 2014 році до 130,4\%о у 2018 році.

Третє рангове місце займали хвороби шкіри та підшкірної клітковини (XII клас), вони становили 11,4\% $(156,5 \%$ ). Показники зростали 3 93,2\%о у 2014 році до 248,4\% у 2016 році і спостерігалося їх зниження до 78,3\%о у 2018 році .

Четверте місце - хвороби кістковом'язової системи та сполучної тканини (XIII клас), вони становили 7\% (94,1\%). Показники захворюваності даного класу хвороб також зростали з 87,1\%о у 2014 році до $136,7 \%$ у 2016 році. У 2018 році спостерігалося їх зниження до 59,6\%.

П'яте рангове місце в структурі захворюваності рядового складу займали хвороби системи кровообігу 
(IX клас), які складали 3,5\% 3 показником захворюваності 47,2\%. У даного класу спостерігалось незначне зростання показників з 29,3\%о у 2014 році до 30,4\%о у 2018 році.

Загальні рівні захворюваності у військовослужбовців строкової служби Північного ОТО за класами хвороб мали тенденцію до збільшення показників 3 $2130,5 \%$ в 2014 році до $2471,9 \%$ в 2018 році.
В структурі загальної захворюваності військовослужбовців строкової служби Північного ОТО перше місце займали хвороби органів дихання (Х клас) 52,2\% 3 показником 978,9\%. Показники даного класу мали тенденцію до зростання з 907\% у 2014 році до $1331 \%$ у 2018 році (рис. 5 ).

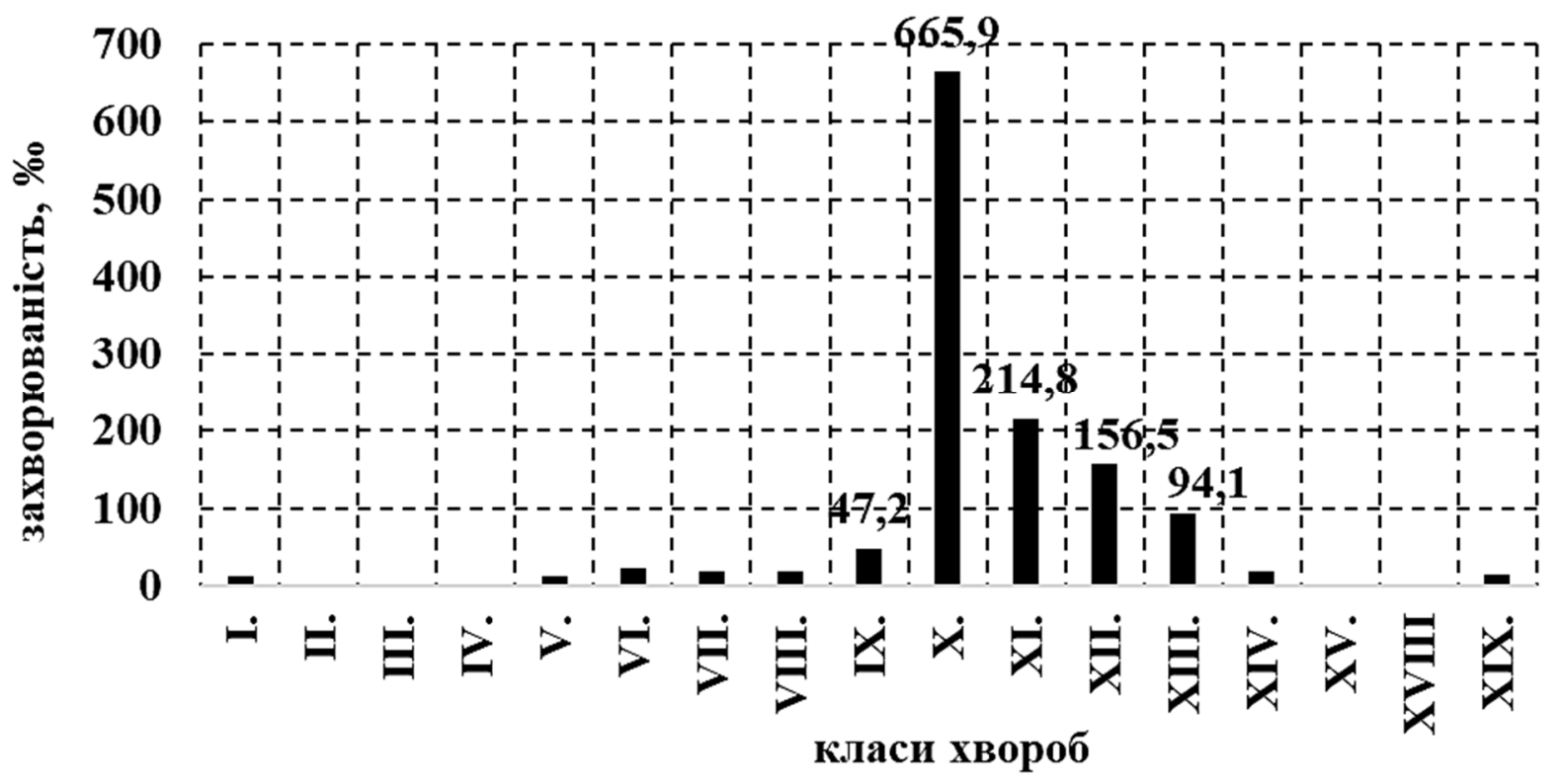

Рис. 4. Показники загальної захворюваності військовослужбовців строкової служби Західного ОТО по класам хвороб в середньому за 2014-2018 роки

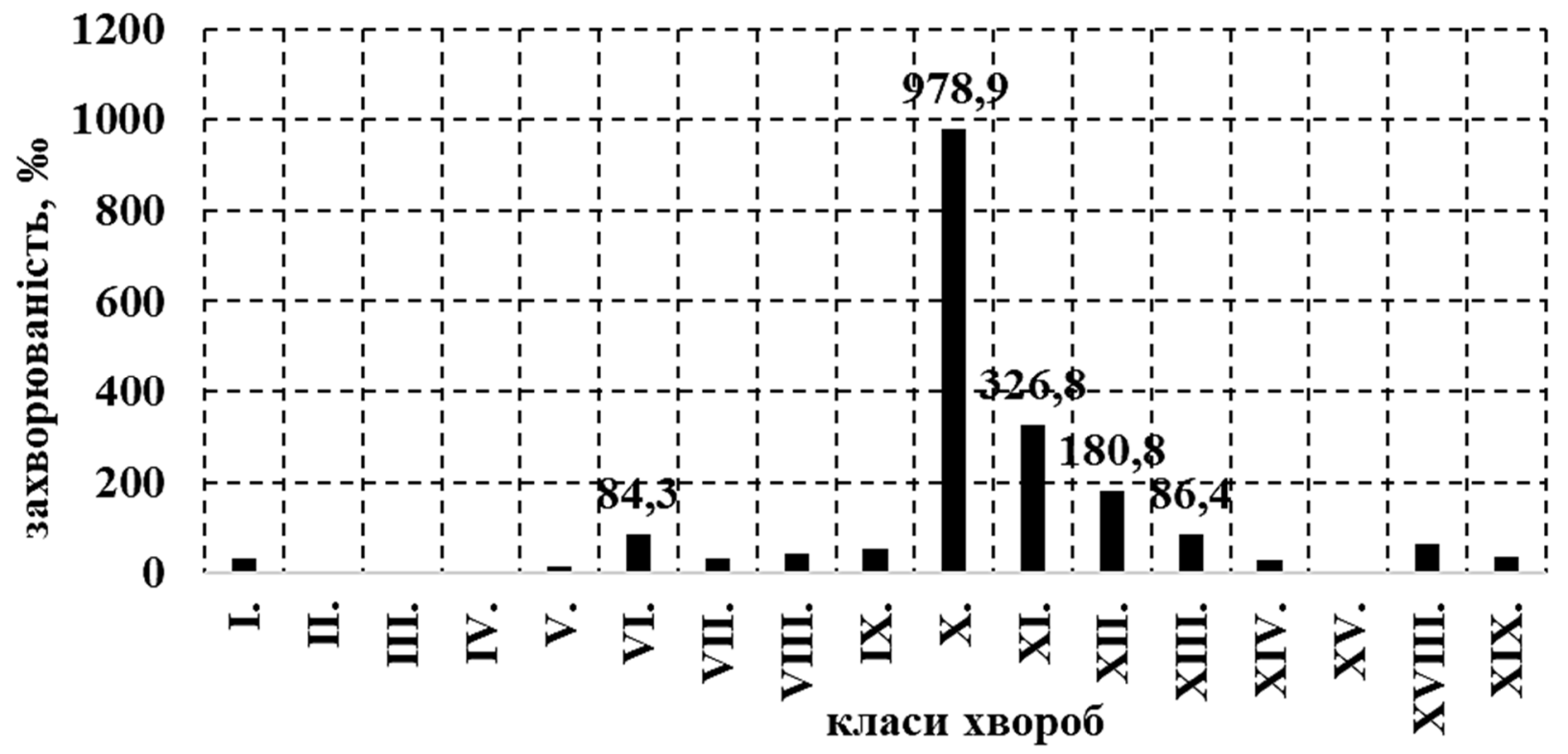

Рис. 5. Показники загальної захворюваності військовослужбовиів строкової служби Північного ОТО по класам хвороб в середньому за 2014-2018 роки

Друге рангове місце в структурі захворюваності рядового складу займали хвороби органів травлення $16,9 \%$ з показником 326,8\%. Показники XI класу мали тенденцію до зростання з 296,9\%о у 2014 році до 463,3\%о у 2018 році.
Третє рангове місце займали хвороби шкіри та підшкірної клітковини (XII клас), вони становили 8,9\% $(180,8 \%$ ). Показники знижувалися з $223,4 \%$ у 2014 році до $167,7 \%$ у 2018 році. 
Четверте місце - хвороби кістковом'язової системи та сполучної тканини (XIII клас), вони становили 4,3\% $(86,4 \%$ ). Відмічалося зниження показників з $125,8 \%$ у 2014 році до $76,7 \%$ у 2018 році.

П'яте рангове місце в структурі захворюваності рядового складу займали хвороби нервової системи (VI клас), які складали 4,1\% 3 показником захворюваності $84,8 \%$. У даного класу також спостерігалось зростання показників з 87,5\% у 2014 році до $110,5 \%$ у 2018 році.

Загальні рівні захворюваності у військовослужбовців строкової служби Південного ОТО за класами хвороб мали тенденцію до значного збільшення показників з 1766,8\%о в 2014 році до 3566,5\%о в 2016 році. У 2018 році спостерігалося їх зниження до 1686,9\%.

$$
\text { В структурі загальної захворюваності }
$$
військовослужбовців строкової служби Південного ОТО перше місце займали хвороби органів дихання (X клас) 45,3\% 3 показником 996,1\%. Відмічалися незначні зміни показників даного класу з 747,1\% у 2014 році до $759,1 \%$ у 2018 році (рис. 6).

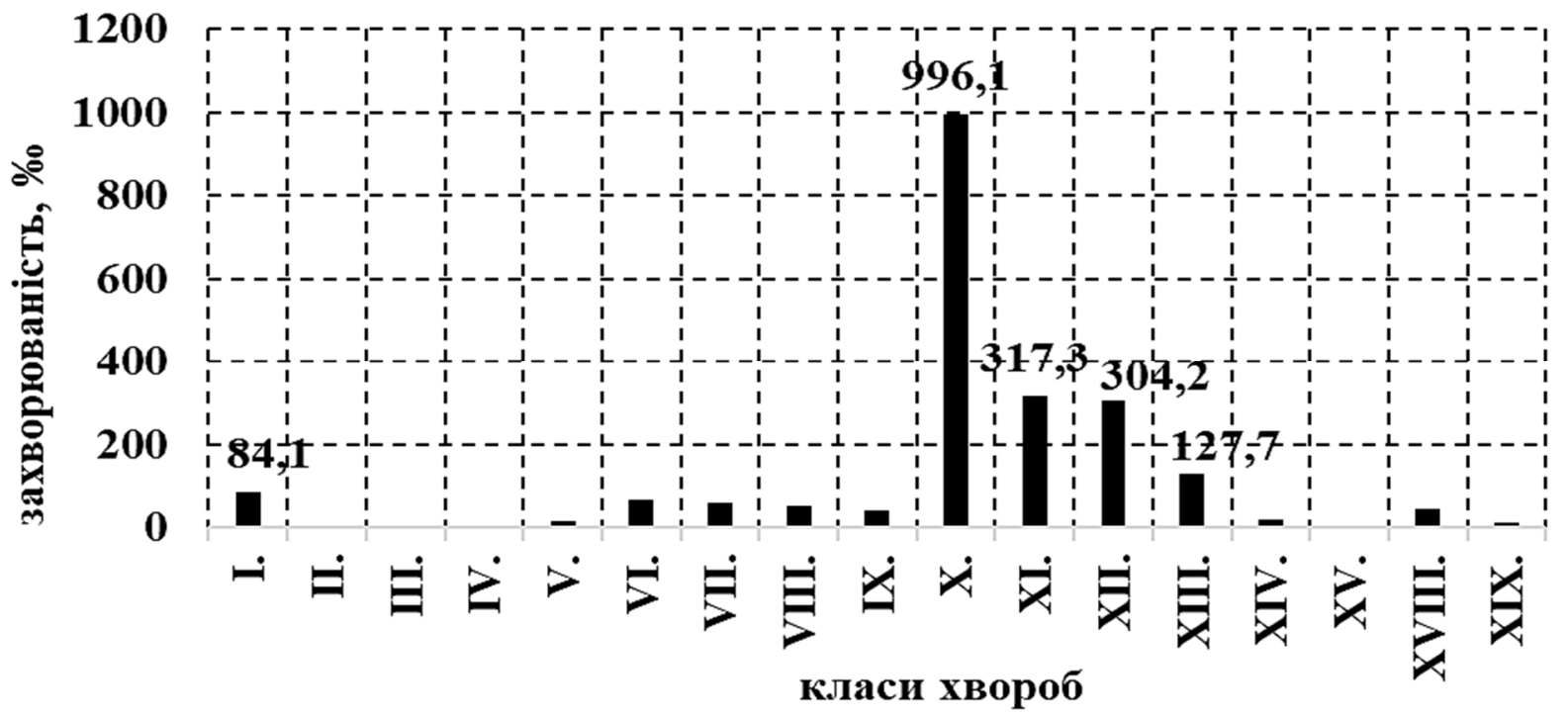

Рис. 6. Показники загальної захворюваності військовослужбовців строкової служби Південного ОТО по класам хвороб в середньому за 2014-2018 роки

Друге рангове місце в структурі захворюваності рядового складу займали хвороби органів травлення $14,8 \% 3$ показником 317,3\%. Показники ХІ класу мали тенденцію до зростання з 220\%о у 2014 році до 290,2\%о у 2018 році.

Третє рангове місце займали хвороби шкіри та підшкірної клітковини (XII клас), вони становили 14,3\% $(304,2 \%$ ). Показники знижувалися з $261,9 \%$ у 2014 році до $218,1 \%$ у 2018 році.

Четверте місце - хвороби кістковом'язової системи та сполучної тканини (XIII клас), вони становили 6,1\% $(127,7 \%$ ). Відмічалося зростання показників з 90\%о у 2014 році до $115 \%$ у 2018 році.

П'яте рангове місце в структурі захворюваності рядового складу займали деякі інфекційні та паразитарні хвороби (I клас), які складали 4,4\% 3 показником захворюваності 84,1\%о. У даного класу також спостерігалось зростання показників з 140,4\% у 2014 році до 139,7\% у 2018 році.

\section{Висновки}

1. Вивчення загальної структури захворюваності військовослужбовців строкової служби НГ України надає загальну уяву про найбільш розповсюджені хвороби, які зустрічаються серед особового складу військ. Це дуже важливо при прогнозуванні та плануванні кадрового та матеріального медичного забезпечення військ.

2. Привертають увагу високі рівні загальної захворюваності на хвороби органів дихання та хвороби органів травлення у всіх Оперативних територіальних об'єднаннях НГ України, що потребує подальшого детального вивчення причин та факторів ризику виникнення цих захворювань.

Перспективи подальших досліджень пов'язані 3 вивченням надання медичної допомоги військовослужбовцям строкової служби Національної гвардії України. 


\section{Література}

1. Волик O.M. Стан здоров'я військовослужбовців Збройних Сил України кадрового складу за даними медичних обстежень / Вісник соціальної гігієни та організації охорони здоров’я України. - 2002. - № 2. - С. 20 -22.

2. Хоженко В.А. К вопросу об оценке здоровья военнослужащих / Военно-медицинский журнал. - 1999. № 8. - C. $18-20$.

3. Проблеми військової охорони здоров’я / Збірник наукових праць УВМА - Випуск 14. - К., 2004. - С. 47.

4. Коваль А.М., Михайлин В.Н. Современные подходы к оценке функционального состояния организма военнослужащих и к коррекции его нарушений / Военно-медицинский журнал. - 2003. - № 4. - С. $33-35$.

5. Вовкодав Н.Н. Госпитализированная заболеваемость военнослужащих ВС Украины / Н.Н. Вовкодав, Н.И. Хижняк, А.С. Кухленко, В.В. Дяченко // Проблемы военного здравоохранения и пути его реформирования. К., 1996. - С. 96-98.

6. Огороднійчук I.B. Захворюваність, госпіталізація та працевтрати військовослужбовців Збройних Сил України 2001-2004 pp. / I.В. Огороднійчук, В.В. Нарожнов, М.І. Хижняк // Проблеми військової охорони здоров’я: 3б. наук. праць УВМА. - К., 2006. - Вип. 15. - С. 505-511.

7. Про Національну гвардію України: Закон України від 13.03.2014 р. № 876- VII // Відомості Верховної Ради України. - 2014. - №17. - Ст. 594 (із змінами від 14.10.2014).

Дата надходження рукопису до редакиії: 01.10.2019 p.

\begin{abstract}
Анализ общих показателей, уровней и структуры заболеваемости военнослужащих срочной службы Национальной гвардии Украины
\end{abstract}

Якимеи В.В. ООО «Органосин ЛТД», г. Ровно, Украина

Цель. Анализ, уровней и структуры заболеваемости среди военнослужащих срочной службы Национальной гвардии (НГ) Украины.

Материалы и методы. Для достижения цели проводился подбор и изучение данных статистических отчетов медицинской службы по форме 264a, проанализированных и обобщенных специалистами лечебно-профилактического отдела Военномедицинского управления Главного управления Национальной гвардии Украины относительно общей заболеваемости военнослужащих.

При этом изучались уровень, структура и динамика заболеваемости среди военнослужащих срочной службы в соответствии с Оперативными территориальными объединениями по основным классам болезней за каждый год в период с 2014 по 2018 год и средние за пять лет с использованием статистического метода исследования.

При распределении классов болезней военнослужащих НГ Украины использована Международная классификация болезней - МКБ-10.

Результаты. Проведенный анализ уровня, структуры и динамики заболеваемости у военнослужащих срочной службы Национальной гвардии Украины на протяжении 2014-2018 годов, результаты которого свидетельствуют о росте показателей заболеваемости среди исследуемого контингента. Изучение общей структуры заболеваемости военнослужащих Национальной гвардии Украины предоставляет общее представление о наиболее распространенных болезнях среди личного состава войск. Это очень важно для прогнозирования и планирования кадрового и материального медицинского обеспечения войск.

Выводы. Изучение общей структуры заболеваемости военнослужащих срочной службы Национальной гвардии Украины предоставляет общее представление о наиболее распространенных болезнях, которые встречаются среди личного состава войск. Это очень важно при прогнозировании и планировании кадрового и материального медицинского обеспечения войск.

Ключевые слова: уровни, показатели заболеваемости, заболеваемость, военнослужащие Национальной гвардии.

\section{Analysis of general indices, levels and structure of morbidity of servicemen of the National Guard of Ukraine}

Jakimec V.V.

TOV “Organosin”, Regional Manager, Rivne, Ukraine

The objective. Analysis of indicators, levels and structure of morbidity among servicemen of the National Guard (NG) conscript service.

Materials and methods. In order to achieve this goal, the selection and study of the statistical reports of the medical service in the form 264a, analyzed and summarized by specialists of the medical-prophylactic department of the Military-medical department of the Main Department of the National Guard of Ukraine on the general morbidity of the servicemen, were conducted.

This examined the level, structure and dynamics of morbidity among conscripts in accordance with the Operational Territorial Associations by major disease classes for each year from 2014 to 2018 and averaged over five years using the statistical survey method. 
When there is a class of twigs, there are national services of Ukraine in Ukraine and the Classification of Twigs is ICD-10.

Results. The analysis of the level, structure and dynamics of morbidity in servicemen of the National Guard of the National Guard of Ukraine during 2014-2018 years, the results of which testify to the increase of morbidity among the studied contingent. The study of the general morbidity of the National Guard of Ukraine provides a general picture of the most common diseases among the personnel. This is very important for the prediction and planning of the personnel and material health support of the troops.

Conclusions. Studying the general morbidity pattern of servicemen of the National Guard of the National Guard of Ukraine provides a general idea of the most common illnesses that occur among the personnel of the troops. This is very important when forecasting and planning the personnel and material health support of troops.

Key words: levels, morbidity rates, morbidity, National Guard troops.

\section{Відомості про автора}

Якимець Володимир Володимирович - ТОВ «Органосін ЛТД», регіональний менеджер; Україна, 30300, м. Рівне, вул. Миколи Хвильового, 2а. 